\title{
Analysis of prescription pattern of anemia in pregnancy: an observational, cross-sectional study
}

\author{
Prasad R. Amrale*, Sagar S. Ahire, Reshma M. Vairage
}

University Research Department, Maharashtra University of Heath Sciences, Nasik, Maharashtra, India

Received: 09 November 2019

Revised: 03 December 2019

Accepted: 04 December 2019

\section{*Correspondence:}

Dr. Prasad R. Amrale,

Email: prasad.amrale.mscpharma18@gmail.com

Copyright: $@$ the author(s), publisher and licensee Medip Academy. This is an open-access article distributed under the terms of the Creative Commons Attribution Non-Commercial License, which permits unrestricted non-commercial use, distribution, and reproduction in any medium, provided the original work is properly cited.

\begin{abstract}
Background: Anemia is a major health problem that affects $25 \%$ to $50 \%$ of the population of the world and approximately $50 \%$ of pregnant women. This research on the use of prescription medicines in anemia during pregnancy remains critically important. Prescribing patterns of the drug in the pregnant women include age, trimester, gravid condition, US-FDA risk category, WHO core indicators.

Methods: A prospective, cross sectional observational multicentric study was conducted in outpatient and inpatient departments of Indira Gandhi Hospital and Civil Hospital in Nasik, for period of 6 months. Ethical approval was taken prior to study from Independent ethics committee. A total of 197 patients were enrolled in the study. Inform consent form was obtained from the patients. After studying them; statistical analysis were done and result and conclusion were drawn.

Results: Out of 197 women's prescriptions, the average number of drug per prescription was 2.14. 27.28\% drugs were prescribed there brand name and $72.72 \%$ by generic name. Iron, folic acid and calcium were prescribed to all pregnant women. The majority of the patients were prescribed category A and category C drugs. No patients were given category $\mathrm{X}$ drug.

Conclusions: Nearly all prescription showed a prescribing practice for writing prophylactic iron and folic acid therapy in all pregnant women. No women was prescribed category X drug. Most of the drug prescribed in generics and thus, prescription pattern of our study set a fine example of prescribing behaviour.
\end{abstract}

Keywords: Prescription pattern, Anemia, Pregnant women, Trimester

\section{INTRODUCTION}

Anemia is a major health problem that affects $25 \%$ to $50 \%$ of the population of the world and approximately $50 \%$ of pregnant women. ${ }^{1}$ Anemia in pregnancy is associated with increased rates of maternal and perinatal mortality, premature delivery, low birth weight, and other adverse outcomes. ${ }^{2}$ During pregnancy, anemia increased more than fourfold from the first to third trimester. ${ }^{3}$ It is a well-established fact that there is a physiological drop in hemoglobin $(\mathrm{Hb})$ in the mid trimester. ${ }^{4}$ This physiological drop is attributed to increase of plasma volume and hence decrease of blood viscosity lead to better circulation in placenta. $^{5}$

The most common cause is iron deficiency anemia, other causes include infection, folate, and vitamin $\mathrm{B}_{12}$ deficiency. ${ }^{6}$ The selected method for hemoglobin assessment was cyanomethemoglobin (WHO/ UNICEF/UNO, 1998). According to the level of haemoglobin, patients were divided into 3 groups; Group 1; $\mathrm{Hb}=8.1-10 \mathrm{gm} / 100 \mathrm{ml}$ (mild anemia) Group 2; 
$\mathrm{Hb}=6.5-8 \mathrm{gm} / 100 \mathrm{ml}$ (moderate anemia) Group 3; $\mathrm{Hb}<6.5 \mathrm{gm} / 100 \mathrm{ml}$ (severe anemia). ${ }^{7}$

Pregnancy usually causes dramatic reversible changes in a woman's cardiovascular system. These remarkable changes begin soon after fertilization and continue throughout gestation to maintain healthy environment for the fetus and mother. The first haemodynamic change during pregnancy seems to be a rise in the heart rate. ${ }^{8}$ In anemia, the oxygen carrying capacity of blood decreases. The following mechanisms operate in anemia to maintain a normal or near normal oxygen supply to the tissues. ${ }^{9}$ Hemodynamic mechanism includes increased cardiac output; blood flow and its distribution; the oxygencarrying capacity of the blood, i.e., haemoglobin concentration; and oxygen extraction. Among all these, the iron requirement also increases during pregnancy for fatal blood formation and iron is required for mothers own blood and cell mass. The degree of iron requirement depends on iron stores and the amount of dietary iron that can be absorbed during pregnancy. Iron depletion and the amount of stored iron are reduced in iron deficiency anemia which limits the red cell production. ${ }^{10}$ Stored iron can be estimated by serum ferritin in iron deficiency anemia. $^{11}$

Pernicious anemia caused by lack of intrinsic factor resulting in lack of absorption of vitamin $B_{12}$ is rare during pregnancy as it usually causes infertility. Women with gastrectomy and ileal disease and resection can have vitamin $\mathrm{B}_{12}$ deficiency. Acquired vitamin $\mathrm{B}_{12}$ deficiency causing megaloblastic anaemia is also uncommon, as the daily requirement of vitamin $\mathrm{B}_{\mathrm{I} 2}$ is only $3.0 \mu \mathrm{g}$ during pregnancy which is easily met with a normal diet. ${ }^{12}$ Only vegans who do not eat any animal-derived substance may have a deficiency of vitamin $B_{12}$ and they should have their diet supplemented during pregnancy. Infestations with diphyllobothriumlatum in some countries can cause megaloblastic anemia due to competitive utilization of ingested vitamin $\mathrm{B}_{12}$ by the parasite. ${ }^{13}$

The provision of iron supplements to pregnant women is one of the most widely practiced public health measures. The traditional treatment of iron deficiency anemia includes oral/ parenteral iron and blood transfusion. Oral iron is associated with side effects, non-compliance and takes a long time to correct anemia. Parenteral preparations like iron dextran, iron sorbitol are associated with anaphylactic reactions and blood transfusions are associated with cross reactions and viral infections. ${ }^{14}$

Regardless of the limited information on the safety of drugs in pregnancy, drug use in pregnancy is common. ${ }^{15,16}$ Supplementary drug treatment like iron, folic acid, calcium, vitamins are prescribed commonly to improve overall nutritional status of mother and fetus. In addition, drugs may also be prescribed for conditions not related to pregnancy such as upper respiratory infections, urinary tract infections and gastrointestinal infections to name some. Also pregnant women are prescribed drugs to treat pre-existing chronic conditions such as diabetes, hypertension or epilepsy or to treat pregnancy related disorders such as pregnancy induced hypertension and gestational diabetes. ${ }^{17}$ Therefore, judicious use of drugs, adequate knowledge, positive approach and awareness towards the drug use are mandatory prerequisites for good maternal and child health. ${ }^{18}$

Our objective of present study was to conduct a prescription pattern of anemia in pregnancy using WHO prescribing indicators and US-FDA drug risk categories. Our secondary objective was to analyse the average number of fixed dose combinations (FDC) per prescription.

\section{METHODS}

This cross sectional observational multicentric study was conducted in outpatient (OP) and inpatient departments of Indira Gandhi Hospital and Civil Hospital in Nasik, for period of 6 months. A total of 197 patients were enrolled in the study. Ethical approval was taken prior to study from independent ethics committee. The visit was done at the antenatal care OPD. Patient data was collected in predesigned data collection form. Inform consent form was obtained from the patients. The data included demographics, patient history of disease and medication, medication from the prescription. The patient's was analysed and drug were categorized according to the USFDA drug risk category.

\section{Inclusion criteria}

Pregnant woman of gestational age of 12 to 34 weeks who were suffering from mild to moderate anemia; patients with age between 18 to 40 years were included in the study.

\section{Exclusion criteria}

Patient diagnosed with severe anemia $\mathrm{Hb}<6.5 \mathrm{gm} / \mathrm{dl}$; patient allergic to iron preparations were excluded from the study.

Prescription pattern parameters were analysed using WHO prescribing Indicators as follows:

- Average number of drugs per encounter.

- Percentage of drug prescribed by generic name.

- Percentage of encounter with an injection prescribed.

- $\quad$ Percentage of drugs prescribed from essential drug list.

And at end, the average number of FDCs per prescription was analysed.

The statistical package for social sciences (SPSS statistics for windows) and Microsoft excel 2010 was used for the analysis of the data. Descriptive statistics such as 
percentages were also measured. Tabulation, graph and diagrams were used to present the data.

\section{RESULTS}

According to the statistical calculation of sample size, a minimum of 196 patients of anemia in pregnancy could be taken. In pre-screening, the number of potentially eligible patients was 220 whereas the number of confirmed eligible patients included in the study was 197.

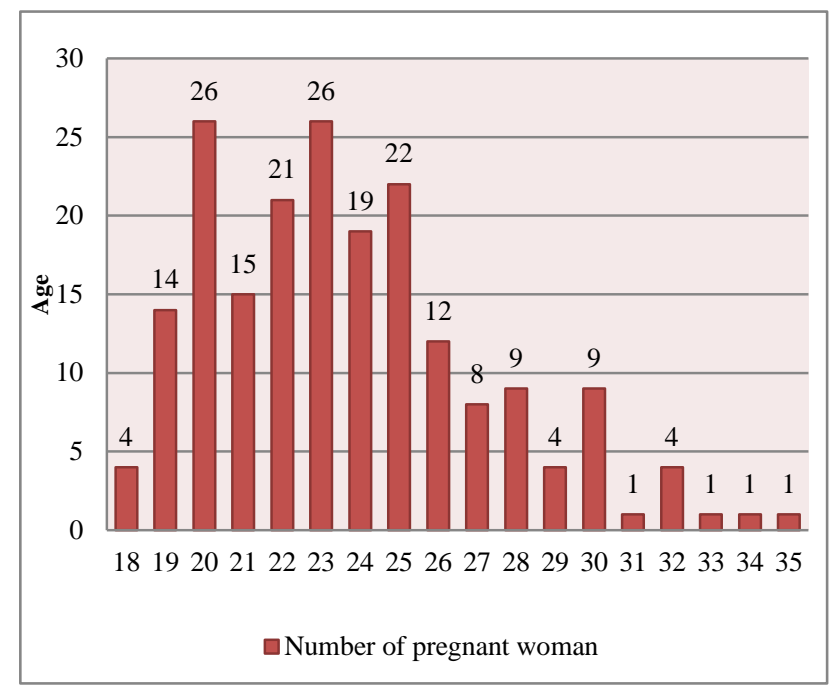

Figure 1: Age wise distribution of patients $(n=197)$.

197 patients included in the study majority (26 pregnant women, $13.19 \%$ ) were in age group of 20 and 23 years followed by $22(11.16 \%)$ pregnant women age group of 25 years, $21(10.05 \%)$ belonged to age group of 22 years, $19(9.64 \%)$ pregnant women age group of 24 years, 15 $(7.61 \%)$ pregnant women in age group of 21 years, 14 $(7.10 \%)$ pregnant women in the age group of 19 years, while the least number were in the range of $12(6.09 \%)$ pregnant women belonged to age group 26 years. Average age of pregnant women was 23.72 years (range 18 to 35 years). The age distribution of patient is shown below (Figure 1).

Out of 197 pregnant women 105 pregnant women of second trimester are mostly seen and followed by pregnant women 52 of third trimester and pregnant women of 40 in first trimester were seen anemic. According to the distribution 174 pregnant ladies had found mild type of anemia and 23 pregnant ladies patient had moderate type of anemia (Figure 2).

Out of 197 pregnant women 105 pregnant women of second trimester are mostly seen and followed by pregnant women 52 of third trimester and pregnant women of 40 in first trimester were seen anemic (Table $1)$.

Gravida condition of pregnant women were seen as multigravida $120(60.92 \%)$ and followed by prime-gravida 77
$(39.08 \%)$ in which the most number of multi-gravida pregnant women $60 \%$ and followed by primi-gravida $40 \%$ (Table 2).

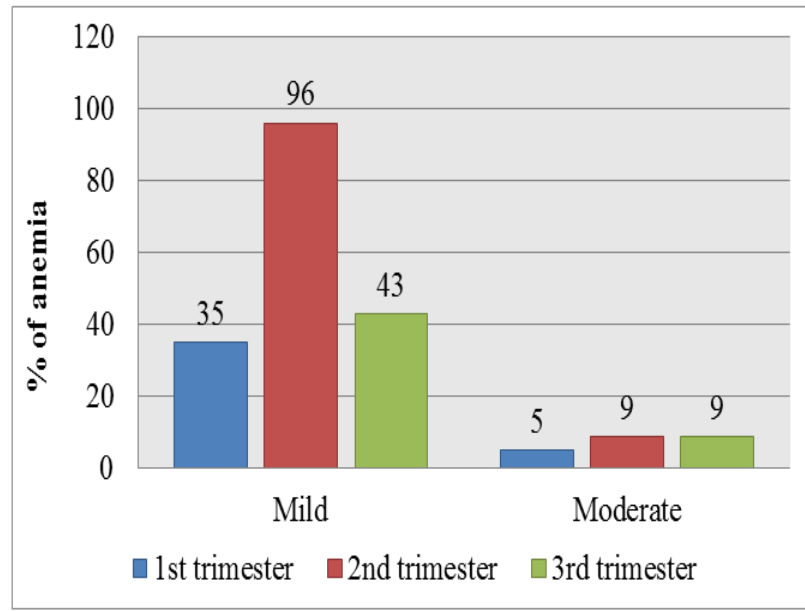

Figure 2: Distribution of woman having mild and moderate and anemia in 1st, 2nd and 3rd trimester according to WHO classification.

Table 1: Trimester wise distribution of patients $(n=197)$.

\begin{tabular}{|lll|}
\hline Trimester & $\begin{array}{l}\text { No. of pregnant } \\
\text { woman }(\mathbf{N})\end{array}$ & $\begin{array}{l}\text { Percentage } \\
(\%)\end{array}$ \\
\hline $\mathbf{1}^{\text {st }}$ & 40 & 20.30 \\
\hline $\mathbf{2}^{\text {nd }}$ & 105 & 53.30 \\
\hline $\mathbf{3}^{\text {rd }}$ & 52 & 26.40 \\
\hline $\begin{array}{l}\text { Total no. of } \\
\text { pregnant woman }\end{array}$ & 197 & 100 \\
\hline
\end{tabular}

Table 2: Gravida condition of patients.

\begin{tabular}{|lll|}
\hline Gravida & $\begin{array}{l}\text { No. pregnant } \\
\text { women }(\mathbf{N})\end{array}$ & $\begin{array}{l}\text { Percentage } \\
(\%)\end{array}$ \\
\hline Primi-gravida & 77 & 39.08 \\
\hline Multi-gravida & 120 & 60.92 \\
\hline $\begin{array}{l}\text { Total no. of } \\
\text { pregnant women }\end{array}$ & 197 & 100 \\
\hline
\end{tabular}

All pregnant women attending the OPD were prescribed iron and folic acid. Out of 197 patient 195 (98.48\%) prescription had drugs iron, folic acid and calcium. Total number of drug prescribed was 11. Among them 5 drugs were in A-category, 1 drug were in B-category, 3 drugs were in C-category, 2 drugs were in D-category and no women was prescribed category-X drugs. Following table shows the distribution of drugs using US-FDA drugs pregnancy category (Table 3 ).

Drug prescribed in OPD in anemic pregnant women classified according to US-FDA drugs pregnancy category: US-FDA drugs pregnancy category seen in mostly in the anemic pregnant women of $5(45.45 \%)$ of risk category A and followed by anemic pregnant women 
$3(27.27 \%)$ C category, anemic pregnant women 2 $(18.18 \%)$ D category, anemic pregnant women of 1
$(9.09 \%)$ B category and anemic pregnant woman of 0 $(0.0 \%) \mathrm{X}$ category as shown in Table 4.

Table 3: List of drug prescribed in OPD for anemic pregnant woman using US-FDA drugs pregnancy category.

\begin{tabular}{|llll|}
\hline Category A & Category B & Category C & Category D \\
\hline Folic acid & $\begin{array}{l}\text { ART (anti-retroviral } \\
\text { drugs) }\end{array}$ & Labetalol & $\begin{array}{l}\text { MVBC (multivitamin) } \\
\text { excess dose }\end{array}$ \\
\hline Iron capsule & Amlodipine & $\begin{array}{l}\text { Proxymate B6 (vitamin } \\
\text { B6) (excess dose) }\end{array}$ \\
\hline Calcium tablet & Nifedipine & \\
\hline Iron and sucrose preparation & & \\
\hline Doxinate & & \\
\hline
\end{tabular}

Table 4: Percentage of prescribed drugs according to US-FDA category.

\begin{tabular}{|lll|}
\hline $\begin{array}{l}\text { US-FDA drug } \\
\text { pregnancy } \\
\text { category }\end{array}$ & $\begin{array}{l}\text { No. of drug } \\
\text { prescribed }(\mathbf{N})\end{array}$ & $\begin{array}{l}\text { Percentage } \\
(\%)\end{array}$ \\
\hline A & 5 & 45.45 \\
\hline B & 1 & 9.09 \\
\hline C & 3 & 27.27 \\
\hline D & 2 & 18.18 \\
\hline X & 0 & 0.0 \\
\hline $\begin{array}{l}\text { Total no. of drug } \\
\text { are prescribed }\end{array}$ & 11 & 100 \\
\hline
\end{tabular}

Commonly prescribed drugs in the study were mostly prescribed folic acid (98.98\%) followed by iron capsule $(98.47 \%)$, calcium tablet $(98.47 \%)$ and iron sucrose injection (13.19\%). Commonly prescribed drugs shown in the Table 5.

Table 5: Commonly prescribed drugs in the study.

\begin{tabular}{|lll|}
\hline Drugs & $\begin{array}{l}\text { No. of pregnant } \\
\text { women }(\mathbf{N})\end{array}$ & $\begin{array}{l}\text { Percentage } \\
(\%)\end{array}$ \\
\hline Folic acid & 195 & 98.98 \\
\hline Iron capsule & 194 & 98.47 \\
\hline Calcium tablet & 194 & 98.47 \\
\hline $\begin{array}{l}\text { Iron and sucrose } \\
\text { injection }\end{array}$ & 26 & 13.19 \\
\hline
\end{tabular}

Table 6: WHO core drug prescribing indicators.

\begin{tabular}{|lll|}
\hline S. no. & Indicators & Value \\
\hline $\mathbf{1}$ & Average no. of drugs per encounter & 0.05 \\
\hline $\mathbf{2}$ & $\begin{array}{l}\text { Percentage of drug prescribed by } \\
\text { generic name }\end{array}$ & 72.72 \\
\hline $\mathbf{3}$ & $\begin{array}{l}\text { Percentage of encounter with an } \\
\text { injection prescribed }\end{array}$ & 13.19 \\
\hline & $\begin{array}{l}\text { Percentage of drug prescribed from } \\
\text { essential drug list }\end{array}$ & 36.36 \\
\hline
\end{tabular}

The indicators of prescribing practices measure the performance of health care providers in several key dimensions related to the appropriate use of drugs. The indicators are based on the practices observed in a sample of clinical encounters taking place at outpatient health facilities for the treatment of acute or chronic illness. Evaluation of drugs based on WHO prescribing indicators. Following table shows the detail findings of WHO core drug prescribing indicators (Table 6).

Out of 197 prescriptions of pregnant women almost 196 (99.49\%) prescription containing fixed dose combinations, only one $(0.51 \%)$ prescription without fix dose combination (Figure 3 ).

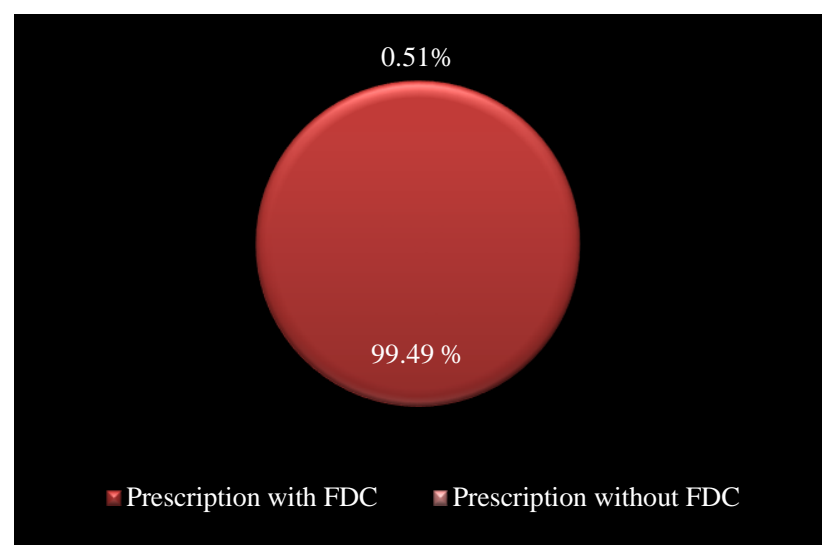

Figure 3: Prescription with and without fixed dose combinations.

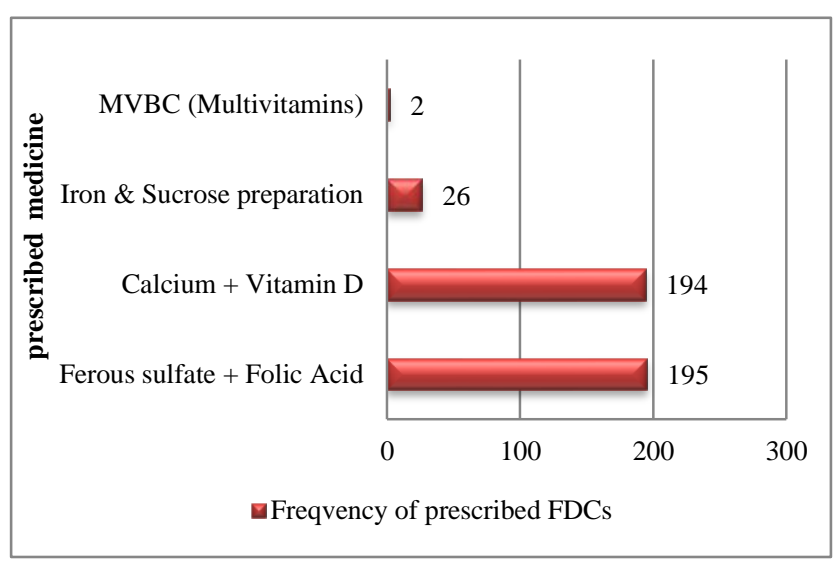

Figure 4: Frequency of prescribed FDCs. 
The prescription of FDCs ferrous salt and folic acid 195 times prescribed and followed by calcium and vitamin D 194 times prescribed, iron and sucrose preparation was 26 times prescribed and MVBC (multivitamin) 2 times prescribed. There is drug interaction between iron and calcium, may affect the absorption of either drug, hence it is advisable to administrate them at some time interval. Following figure shows the frequency of prescribed FDCs (Figure 4).

\section{DISCUSSION}

This study is provided a data on prescription pattern of the drug on anemia in pregnancy in gynaecology department of Indira Gandhi Hospital and Civil hospital Nasik. A total of 197 patient were enrolled based on inclusion and exclusion criteria in the study US-FDA drug risk category out of 197 patient included in the study majority (26 pregnant women, 13.19\%) were in age group of 20 and 23 years followed by $22(11.16 \%)$ pregnant women age group of 25 years, $21(10.05 \%)$ belonged to age group of 22 years, $19(9.64 \%)$ pregnant women age group of 24 years, $15(7.61 \%)$ pregnant women in age group of 21 years, $14(7.10 \%)$ pregnant women in the age group of 19 years, while the least number were in the range of 12 (6.09\%) pregnant women belonged to age group 26 years. Average age of pregnant women was 23.72 years (range 18 to 35 years). This finding was almost similar to the Yadav et al. ${ }^{19}$

Out of 197 pregnant women 105 pregnant women of second trimester are mostly seen and followed by pregnant women 52 of third trimester and pregnant women of 40 in first trimester were seen. Gravida condition of pregnant women were seen as multi-gravida $120(60.92 \%)$ and followed by primi-gravida 77 $(39.08 \%)$. This finding was similar to Yadav et al in which the most number of multi-gravida pregnant women $60 \%$ and followed by primi-gravida $40 \%$. $^{19}$

The average number of drug is found to be 2.14 (range 24) per prescription. The maximum number of drugs prescribed was 4 in two women. This is because one of them had hypertension and the other had vomiting. Out of 197 pregnant women, 2 women presented a history of vomiting, 2 women presented a history of hypertension and 1 woman was HIV positive patient, she was continued her ART.

The iron supplementation is strongly recommended in developing countries. Supplement of iron the treatment of choice and almost all women should be treated effectively with oral or parenteral preparation, depending on $\mathrm{Hb}$ level and gestational age. All pregnant women attending the OPD were prescribed iron and folic acid. Out of 197 patients 195 (98.48\%) prescription had drugs iron, folic acid and calcium. Total number of drug prescribed was 11. Among them 5 drugs were in A-category, 1 drug were in B-category, 3 drugs were in C-category, 2 drugs were in D-category and no women was prescribed category-X drugs. This finding is similar to Gawade et al. ${ }^{20}$

Evaluation of drugs based on WHO prescribing indicators; average number of drug per encounter was 0.05 ; percentage of dug prescribed by generic name was 72.72; percentage of an encounter of an injection prescribed was 13.19; percentage of drug prescribed from essential drug list was 36.36. This result was almost similar to Yadav et al. ${ }^{19}$

Out of 197 prescriptions of pregnant women almost 196 (99.49\%) prescription containing fixed dose combination. Only one prescription without fix dose combination. The prescription of FDCs ferrous salt and folic acid 195 times prescribed and followed by calcium and vitamin D 194 times prescribed, iron and sucrose preparation was 26 times prescribed and MVBC (multivitamin) 2 times prescribed. There is drug interaction between iron and calcium, may affect the absorption of either drug, hence it is advisable to administrate them at some time interval.

\section{CONCLUSION}

Nearly all prescription showed a prescribing practice for writing prophylactic iron and folic acid therapy in all pregnant women. Some of the prescription showed that additional drugs were prescribed only if required. No women was prescribed category X drug. Most of the drug prescribed in generics and. Thus, prescription pattern of our study set a fine example of prescribing behaviour.

\section{Limitations}

In this study follow up was not possible because the study participants were from small cities and rural areas with limited medical facilities.

\section{ACKNOWLEDGEMENTS}

We would like to thank all the participants and the patients for being a part of this study. We also very thankful to Indira Gandhi hospital staff and Civil Hospital staff, Nasik, because they allow us and help us to conduct our research study.

\section{Funding: No funding sources}

Conflict of interest: None declared

Ethical approval: The study was approved by the Institutional Ethics Committee

\section{REFERENCES}

1. Ahankari A, Leonardi-Bee J. Maternal hemoglobin and birth weight: systematic review and metaanalysis. Int J Med Sci Public Health. 2015;4(4).

2. Sukrat B, Wilasrusmee C, Siribumrungwong B, McEvoy M, Okascharoen C, Attia J, et al. Hemoglobin concentration and pregnancy outcomes: a systematic review and meta-analysis. BioMed Res Int. 2013;2013:769057 
3. Chang S-C, O'Brien KO, Nathanson MS, Mancini J, Witter FR. Hemoglobin concentrations influence birth outcomes in pregnant African-American adolescents. J Nutr. 2003;133(7):2348-55.

4. Kalaivani K. Prevalence and consequences of anaemia in pregnancy. Indian $\mathbf{J}$ Med Res. 2009;130(5):627-33.

5. Tan EK, Tan EL. Alterations in physiology and anatomy during pregnancy. Pract Res Clin Obstetr Gynaecol. 2013;27(6):791-802.

6. Akhtar M, Hassan I. Case report of severe anaemia during late pregnancy. Hindawi Publish Corp Case Reports Obstetr Gynecol. 2012:485452:3.

7. MoghaddamTabrizi F, Barjasteh S, maternal hemoglobin levels during pregnancy and their association with birth weight of neonates. Iranian $\mathbf{J}$ Pediatr Hematol Oncol. 2015;15(4):212-7.

8. Campos O. Doppler echocardiography during pregnancy: physiological and abnormal findings. Echocardiography. 1996;13(2):135-46.

9. Tang YD, Katz SD. Anaemia in Chronic Heart Failure. Circulation. 2006;118:2454-61.

10. Bothwell TH. Iron requirements in pregnancy and strategies to meet them 1, 2, 3. Am J Clin Nutr. 2000;72(1):257-64.

11. Puolakka J, Janne O, Pakarinen A, Vihko R. Serum ferritin in the diagnosis of anaemia during pregnancy. Acta Obstet Gynecol Scand Suppl. 1980;95:57-63.

12. Scott JM, Weir DG. Role of folc acid /folate in pregnancy prevention is better than cure. Recent Adv Obst Gynaecol. 1998;20:1-20.

13. Sharma JB, Shankar M. Anemia in pregnancy. JIMSA. 2010;23(4):253-60.
14. Abhishilani GD, Sagili H, Reddy R. Intravenous iron sucrose and oral iron for the treatment of iron deficiency anaemia in pregnancy. J Clin Diagnos Res. 2014;8(5):4-7.

15. Briggs GG, Greeman RK, Yaffe SJ. Drugs in pregnancy and lactation: a reference guide to fetal and neonatal risk, 6th ed. Philadelphia: Lippincott Williams and Wilkins; 2002.

16. Mitchell AA, Gilboa SM, Werler MM, Kelley KE, Louik C, Hernandez-Diaz S. Study T.B.D.P. Medication used during pregnancy, with particular focus on prescription drugs: 1976-2008. Am J Obstet Gynecol. 2011;205(1):51-8.

17. Splinter MY, Sagraves R. Prenatal use of medications by women giving birth at a university hospital. South Med J. 1997;90:498-502.

18. Adhikari A, Biswas S, Gupta RK. Drug use behaviour of pregnant women in rural India. J Pak Med Assoc. 2011;61(4):381-3.

19. Yadav S, Evangeline GS. Prescribing pattern of drug on pregnant woman attending a teaching hospital. Int J Pharmacol Therap. 2016;6(1):9-26.

20. Gawde SR, Bhide SS, Patel TC, Chauhan AR, Mayadeo NM, Sawardekar SB. Drug prescription pattern in pregnant women attending antenatal outpatient department of a tertiary care hospital. Br J Pharma Res. 2013;3(1):1-12.

Cite this article as: Amrale PR, Ahire SS, Vairage RM. Analysis of prescription pattern of anemia in pregnancy: an observational, cross-sectional study. Int J Basic Clin Pharmacol 2020;9:63-8. 